\title{
Transatlantica
}

Revue d'études américaines. American Studies Journal

$1 \mid 2010$

American Shakespeare / Comic Books

\section{The Influence of Shakespearean Theatricality on Emily Dickinson's Lyrical Self}

Adeline Chevrier-Bosseau

\section{(2) OpenEdition}

1 Journals

\section{Édition électronique}

URL : https://journals.openedition.org/transatlantica/4901

DOI : 10.4000/transatlantica.4901

ISSN : $1765-2766$

Éditeur

Association française d'Etudes Américaines (AFEA)

Référence électronique

Adeline Chevrier-Bosseau, «The Influence of Shakespearean Theatricality on Emily Dickinson's Lyrical Self », Transatlantica [En ligne], 1 | 2010, mis en ligne le 27 septembre 2010, consulté le 10 février 2023. URL : http://journals.openedition.org/transatlantica/4901 ; DOI : https://doi.org/10.4000/ transatlantica. 4901

Ce document a été généré automatiquement le 10 février 2023.

Creative Commons - Attribution - Pas d'Utilisation Commerciale - Pas de Modification 4.0 International - CC BY-NC-ND 4.0

https://creativecommons.org/licenses/by-nc-nd/4.0/ 


\title{
The Influence of Shakespearean Theatricality on Emily Dickinson's Lyrical Self
}

\author{
Adeline Chevrier-Bosseau
}

“This thing of darkness I / Acknowledge mine."

(The Tempest, V, 1, 275-6)

1 Emily Dickinson lived and wrote in an era when Shakespeare had become omnipresent in American culture; whether his works were parodied or highly praised, his authorship challenged, and his life was the object of many discussions and wild conjectures; the man and his works were discussed in all social milieus. As Lawrence W. Levine notes in Highbrow/Lowbrow, The Emergence of Cultural Hierarchy in America, "Nineteenth-century America swallowed Shakespeare, digested him and his plays, and made them part of the cultural body" (Levine 24). Amherst was no exception, despite the ambiguous relationship of New England writers like Emerson with Shakespeare ${ }^{1}$ and the puritan reserve towards the theatrical world. For a nineteenth-century woman born and raised in New England by a rather strict and stern father, Emily Dickinson was surprisingly well acquainted with shakespeare and his works. Given the extensive quotations of Shakespeare in her correspondence and poems, it is obvious that Dickinson had had access to the full texts, and not to simplified or censored versions of Shakespeare, as was often the case for young ladies in her time ${ }^{2}$. She also took part in the Shakespearean debates that animated Amherst's social and cultural life in the 1850s. Indeed, most of her brother Austin's friends - George Gould for example ${ }^{3}$ - were Amherst College students or graduates, and so were the tutors of the Shakespeare club she attended. In that sense, Dickinson was perfectly aware of the ongoing debates. Shakespeare's works were read and discussed during club meetings, as well as in many passionate articles published in The Indicator and Amherst Collegiate Magazine. As a great admirer of Shakespeare's works, Dickinson always defended them, refusing any form of censorship of the texts in meetings of the Shakespeare club ${ }^{4}$, or discarding the controversy on the authorship of Shakespeare's works that was sparked by Delia Bacon's article "William Shakspeare and his Plays; an Enquiry Concerning Them," 
published in 1856 in Putnam's Magazine ${ }^{5}$. Shakespeare was the absolute and unsurpassable model, as she expressed most famously in a letter to the editor of the Springfield Republican, Franklin B. Sanborn: "Had I a trait you would accept I should be most proud, though he has had his Future who has found Shakespeare" (L_402).

In his remarkable study of the social and cultural context in which Dickinson read Shakespeare, Páraic Finnerty has strongly asserted the importance of Shakespeare for the poet, not only as a writer she greatly admired, but as a literary model. The purpose of this paper is not to elaborate on this study and propose a systematic intertextual reading of the two authors through a commentary on every reference to Shakespeare in Dickinson's works, but to focus on the way Shakespearean theatricality has influenced the shaping of her literary self. The dramatic quality of Dickinson's poems and letters has often been noted by critics: the notion of performance is indeed central to Emily Dickinson's work, not only in the adoption of her famous personae - the wife, the child, etc... - but also in the workings of the lyrical voice, and the construction of her lyrical self. This paper thus wishes to emphasize the underlying dramatic dimension in Dickinson's performance of the self, and the way Dickinsonian lyricism has been influenced, in many respects, by Shakespearean theatricality.

We will first turn to the self-fashioning of Dickinson's literary persona, by studying how she represented herself in her early letters to Higginson and to her brother Austin - when she was still shaping her identity as a poet - and the response this selffashioning triggered in her audience. We will argue that Dickinson created her literary myth along the lines of the Shakespearean myth. In My Emily Dickinson, Susan Howe asserts that Shakespeare was the "supreme source" (Howe 71) for Dickinson's poems. She also highlights the dramatic quality of Dickinson's writing by emphasizing its ties to the genre of the dramatic monologue ${ }^{6}$. As Cornelia Pearsall explains, the dramatic monologue reveals a chameleon self, that is both created and constantly diffracted through language: "the act of the dramatic monologue [...] simultaneously creates a self and alters that self" (Pearsall 84). The already complex negotiations of identity at work in the dramatic monologue are further complicated in Dickinson's poems because of the Shakespearean intertext, especially with the manipulation of Shakespearean crossdressed voices. We shall thus finally focus on the performance of selfhood in Dickinson's poems, and on the problematic relation between the poet's elusive voice and the reader.

\section{"I must tell you about the character of Amherst"7- Dickinson's self-fashioning of her public persona}

In the wake of Emerson's plea for a wholly new and independent American literature in "The American Scholar," Shakespeare was often regarded by Dickinson's contemporaries as the iconic figure that needed to be surpassed, the literary "father" who needed to be killed. According to Marianne Novy, Dickinson's unwavering admiration for the Bard - in contrast to her male contemporaries' challenging of the literary myth - could be explained by the fact that women writers, especially in the nineteenth century, felt a strong kinship toward and identified with Shakespeare: for Dickinson, the Bard was not only a literary model - she considered him as much as a teacher as Higginson or Susan were to her. In a letter she wrote to her sister-in-law and lifelong friend towards the end of her life, Dickinson thus wrote: "Dear Sue - With the 
exception of Shakespeare, you have told me of more knowledge than any one living To say that sincerely is strange praise" (L_757, 1882). In her introduction to the collection of essays entitled Women's Re-visions of Shakespeare, On the Responses of Dickinson, Woolf, Rich, HD, George Eliot and Others, Novy explains:

Three images of Shakespeare have particular resonance for women's history: the outsider, the artist of wide-ranging identification, and the actor. [...] In the seventeenth and most of the eighteenth century, before Shakespeare was enshrined in the literary canon, he had a cultural image as an outsider to many established institutions. He lacked university education; he wrote in the popular form of the drama, rather than the most prestigious form of the epic; and he broke many of the rules of dramatic construction favored by literary critics. [...] There are good historical reasons why women writers, and even women readers, might feel analogously outside literary institutions and might take this Shakespeare as a model who showed that they could succeed anyway. (Novy 2-3)

Novy's last remarks seem particularly fitting for Dickinson, whose work remained virtually unpublished while she lived, and whose style Higginson referred to as being "spasmodic" and too unruly to be presented to readers. Similarly, this image of Shakespeare as an "outsider" seems indeed to have appealed to Dickinson, since in many respects, she was a self-proclaimed outcast, setting herself apart from the very first letters she sent to Higginson, with her strange writing style and extravagant posing, that could not have failed to distinguish her from the multitude of hopeful writers that responded to Higginson's Letter to a Young Contributor'9. In her second letter to him, Emily Dickinson - then aged 31 - represents herself as a strange and solitary girl in need of guidance:

You ask of my Companions Hills - Sir - and the Sundown - and a Dog - large as myself, that my father bought me - They are better than Beings - because they know - but do not tell - and the noise in the Pool, at Noon - excels my Piano. I have a Brother and Sister - My Mother does not care for thought - and Father, too busy with his Briefs - to notice what we do - He buys me many Books - but begs me not to read them - because he fears they joggle the Mind. They are religious - except me - and address an Eclipse, every morning - whom they call their 'Father'. But I fear my story fatigues you - I would like to learn - Could you tell me how to grow or is it unconveyed - like Melody - or Witchcraft? (L_261)

6 This self-description is uncannily reminiscent of Hawthorne's character Pearl in The Scarlet Letter: like Pearl, Dickinson seems to shun the company of human beings ${ }^{10}$, preferring that of the "Hills," "the Sundown" and her Dog ("They are better than Beings - because they know - but do not tell"). She thus appears as a wild child, a little witch refusing to acknowledge the existence of a "heavenly Father"11 "They are religious - except me - and address an Eclipse, every morning - whom they call their 'Father"'). Throughout her correspondence with her "mentor," Dickinson persistently represented herself as inexperienced and innocent, and refused to send him a portrait or reveal her age $\mathrm{e}^{12}$ in order to maintain her aura of mystery.

Dickinson's letters to Higginson follow the dynamics of play - as defined by Benveniste, Caillois or Winnicott ${ }^{13}$ - and become closed entities in which real identities are replaced by personae abiding by the rules of the game, Dickinson being the "half-cracked poetess," the childish pupil, and Higginson the wise mentor - two roles they kept playing until the poet's death. Since she was told very early in her correspondence with Higginson that her poems would not be published, and went into almost complete seclusion in the 1860s, her letters soon became her only public interface, as well as the only means of circulation for her poems. In addition, letters were often read aloud to 
friends or family members (Finnerty 49), thus offering a form of stage by proxy to Dickinson's epistolary persona ${ }^{14}$, who, in return, always remained a sort of virtual character, inhabiting a literary space. Dickinson's histrionic persona changes roles depending on the targeted audience and the circumstances that dictate the performance. This phenomenon is best exemplified in her correspondence with Higginson, as well as with her brother Austin, in which she successively plays Hepzibah (L_62, November 1851) and Rosalind (L_110, March 1853), whereas Austin is associated with Clifford and Oliver ${ }^{15}$. Emily Dickinson's histrionic conception of her literary and public self can in part be accounted for by her profound admiration of the Bard and his own "protean flexibility of identity" (Novy 4). Indeed, according to Marianne Novy, women writers identified with Shakespeare in the process of constructing their own identity as writers because

in relation to [him] they could also see creativity as appropriation. Perhaps this image of creativity might be particularly congenial because of the flexibility of ego boundaries and ease of identification with others shared by many women in our culture. These traits, attributed by the psychiatrist Nancy Chodorow to the gendering of child-rearing patterns, provide a reason why women find it appealing to develop their creativity in part by identification with another writer, and might be especially likely to construct their image of the ideal writer as one who also has flexible ego boundaries and ease of identification. (Novy 5)

8 We could thus argue that, because of her identification with "Shakespeare the actor" (Novy 2), Dickinson's dramatization and fictionalization of herself could be compared to Shakespeare's own fashioning of his public self, as described by Stephen Greenblatt in his study Renaissance Self-fashioning: From More to Shakespeare. According to Greenblatt, "[self-fashioning] invariably crosses the boundaries between the creation of literary characters, the shaping of one's identity, the experience of being molded by forces outside one's control, the attempt to fashion other selves" (Greenblatt 3). In the correspondence of the young poet with her mentor, as well as in her early correspondence with her brother (with whom she shared an intellectual, artistic - and some would say sentimental ${ }^{16}$ - rivalry), Dickinson definitely crosses such boundaries. She is in both cases simultaneously shaping her artistic identity, posing as a fictive or literary character, and trying to comply with "forces outside [her] control" - namely, nineteenth-century conventions of modesty and ladylike behavior - by ironically enacting the part of a timid overgrown child ${ }^{17}$ or that of the falsely submissive sister.

9 The impact of this "blurring of the boundaries" between the self and a literary character is particularly obvious in Mabel Loomis Todd's description of "the Myth" in a letter written to her parents upon her arrival in Amherst:

I must tell you about the character of Amherst. It is a lady whom the people call the Myth. She is a sister of Mr. Dickinson and seems to be the climax of all the family oddity. She has not been outside of her own house in fifteen years, except once to see a new church, when she crept out at night, and viewed it by moonlight. [...] She dresses wholly in white, and her mind is said to be perfectly wonderful. She writes finely, but no one ever sees her. Her sister, who was at Mrs. Dickinson's party, invited me to come and sing to her mother some time and I promised to go and if the performance pleases her, a servant will enter with wine for me, or a flower, and perhaps her thanks; but just probably the token of approval will not come then, but a few days later, some dainty present will appear for me at twilight. People tell me that the myth will hear every note - she will be near, but unseen... Isn't that like a book? So interesting. (Sewall 216) 
The description of Dickinson as a strange creature - werewolf or vampire - "creep[ing] out at night" and making presents "appear at twilight" seems heavily influenced by topoï of the gothic genre. Todd's final remark, "Isn't that like a book?", and her use of the term "character" in reference to Dickinson, insist on the fictional dimension of this strange personage. In a journal entry written a few months later, Todd compares Dickinson to Miss Havisham, and, through this comparison with Dickens's character, hints that a lost love would be the reason for her withdrawal from public life. Todd's letter illustrates the completion of the fictionalizing process, and the reception of Dickinson's performance by her audience. It also testifies to how a sensational although, paradoxically, invisible - show of an "odd" "woman in white" (tailored along nineteenth-century literary topoï that would not fail to find an echo in the audience - as Todd's many allusions to the gothic genre seem to confirm) would have been received in a small town like Amherst. Overall, Dickinson's puzzling behavior has fostered countless hypotheses, from her contemporaries to critics alike - a mechanism that is also applicable to Shakespeare, whose life remains quite mysterious, and has consequently become a perfect object of speculation. Páraic Finnerty thus argues that Dickinson might in fact have been influenced by the Shakespearean myth in the forging of her own:

The myth of Shakespeare's unsurpassable genius is generated and facilitated by the absence of a biography. Bacon's thesis suggests how Dickinson will become the myth of Amherst, who, as Mabel Loomis Todd noted in 1881, "no one ever sees." (Finnerty 65)

11 Taking her cue from Shakespeare, Dickinson shaped her own myth by removing herself from the public eye ${ }^{18}$, and by developing an ever-changing fictionalized persona in her only "public" sphere, her letters - which shrouded her identity as effectively as the multitude of reflections in a house of mirrors makes it impossible for an onlooker to discern the real self from the reflections.

This mode of self-fashioning, which repeatedly distorts the image of the self according to the targeted audience, is also often akin to a freakifying of the self: one of the most striking examples could be found in a July 1862 letter to Higginson, in which Dickinson refers to herself as "the only Kangaroo among the Beauty" (L_268). This image corresponds to the criteria of the grotesque as established by Bakhtin, in the sense that it blends animal and human elements (Bakhtin 314-315). The self is associated with a "Kangaroo," an unusual animal which can be seen as a parody of human beings, since kangaroos usually stand on their hind legs. The fact that the kangaroo should be presented as grotesquely standing out "among the Beauty" conveys the image of a strange animal standing in a parlor, supposedly, among beautiful ladies, and is reminiscent of Act III, scene one of Shakespeare's A Midsummer Night's Dream, in which Bottom's asinine head contrasts with the daintiness of the fairies. This contrast, as well as the dimension of parody, are underlined by the dissonant association of the [u:] of "Kangaroo" and the [ju:] of "Beauty": not only does the [u:] sound like a parody of the second, but - knowing Dickinson's Shakespearean penchant - this [u:] could also be heard as an echo to Bottom's song in the same passage of the play, and more particularly to the term "cuckoo," repeated twice in Bottom's song, with the same grotesque effect ${ }^{19}$.

13 Apart from such Shakespearean grotesque blending of the high and the low (Farnham 34-35), Dickinson's subversive representations of herself should also be replaced in the 
perspective of the nineteenth-century culture of exhibition. In an article entitled "P.T. Barnum's Theatrical Selfhood and the Nineteenth-Century Culture of Exhibition," Eric Fretz describes the nineteenth century as "an era of exhibitionism that privileged appearance over essence" (Fretz 98), and explains that such a concealing of one's true self behind a public persona was a common phenomenon:

By the mid-nineteenth century the ideal of the unadorned private man had given way to the reality of the public confidence man, or painted woman, who concealed or transformed his or her private nature in the construction of a public identity.

(Fretz 98)

14 In this context, the "public selves on display" worked as "ideological mirrors," at once reflecting and distorting established conceptions of selfhood: "The exhibition culture of the nineteenth century was a site of cultural exchange and conflict, and the public display of theatrical selfhood both confirmed and implicitly challenged middle-class values" (Fretz 105). In this perspective, Emily Dickinson's self-fashioning as some freakish woman-child relies both on a reflection and on a distortion of the Victorian cliché of women as pure, modest "angels in the house," while also following the dynamics of conflict which are typical of Renaissance self-fashioning as defined by Greenblatt: "Self-fashioning is achieved in relation to something perceived as alien, strange, or hostile. This threatening Other [...] must be discovered or invented in order to be attacked and destroyed" (Greenblatt 9). There is a good deal of irony in Dickinson's use of her public self, which subverts the Victorian ideal of modesty by making this very quality, enacted by the complete withdrawal from the public eye, the reason for the persona's hypervisibility.

\section{"I am not what I am" (Twelfth Night, III, 1, 140): the performance selfhood in Dickinson's poems}

15 In one of her first (and most famous) letters to Higginson, Dickinson wrote: "When I state myself, as the Representative of the Verse - it does not mean - me - but a supposed person" (L_268). Identity is thus also - and perhaps even more so - a matter of performance in her poetry, mainly because the conception of the self as a projection, as being the subject performing the utterance, is intrinsic to the lyric genre, in which the lyric "I" is precisely a "supposed person" (Combe 39), i.e. an entity that can wear various costumes and adopt various roles. Indeed, Dickinson's poetic body of work is peopled by various personae, among which biblical and Shakespearean characters (Shylock appears in poem *247 "What would I give to see his face?", Hamlet, Romeo and Juliet are all evoked in the third stanza of poem *741 "Drama's Vitallest Expression is the Common Day"). For the purpose of this paper, we will not necessarily focus on these particular Shakespearean occurrences, but rather on the way the dramatic quality, inherent to the lyric genre, is emphasized in some of Dickinson's poems through the close association with Shakespearean theatricality, as it is the case for example with poem *199 "I'm "wife" - I've finished that - ":

I'm "wife" - I've finished that -

That other state -

I'm Czar - I'm "Woman" now

It's safer so -

How odd the Girl's life looks

Behind this soft Eclipse - 
I think that Earth feels so

To folks in Heaven - now -

This being comfort - then

That other kind - was pain -

But why compare?

I'm "Wife"! Stop There!

The first stanza features a rapid series of changes in the subject's identity, from an unnamed anterior state to that of "wife," "Czar," and "woman." All those different states follow one another so closely that they don't seem to be granted the time to have an actual existence; as they are linked together by the dashes, working like pauses and signaling the passage to another state, they appear as a mere succession of images, as if one was flipping through a series of cartoons or snapshots of the self in various costumes. In her chapter "The poet as cartoonist," Martha Nell Smith has retraced the importance of illustrations in Dickinson's manuscripts: the images of the self - as a woman, as a wife, or as a czar - presented in this poem recall the clippings that Dickinson used to superpose to some of her poems (like poem *78 "A poor - torn heart - a tattered heart" for example) and letters (L_33 to William Cowper Dickinson or L_214 to Susan ${ }^{20}$. This impression is reinforced by the presence of quotation marks, which seem to literally cut out the words from the stanza and make them stand out. The poem thus presents fleeting performances of identity, quick as a succession of snapshots; the term "performance" is here to be understood both in its linguistic sense, as a performative utterance, and in its theatrical sense, since the self is both making a performative speech act - taking on the role of a "wife," a "woman" or a "czar" as the given word is uttered - and performing these roles for the reader. Indeed, the various denominations - "wife," "girl," or "woman," all stereotypical denominations of womanhood - function metonymically as repeated subjectivating norms determining and enabling the performance of the gender and social status of the speaker (Butler in Case 270). Among this kaleidoscopic vision of a fragmented feminine identity, the irruption of the word "Czar" in the third line is thus somehow puzzling, all the more so because it is deprived of quotation marks, as if it were unobtrusively placed there. As a symbol of male power, "Czar" has a more exotic twist than "King;" it has a particular resonance in the nineteenth-century context, since, as Marjorie Garber explains, oriental objects were all the rage during that period ${ }^{21}$ (Garber 314). In addition to being part of the fantasized image of the Oriental (man or woman, incidentally), the oriental costume, and in particular the loose-fitting Turkish trousers, was particularly fashionable on the nineteenth-century stage: "On the British and American stage, in the years between Mrs Siddons and Sarah Bernardt, Aladdin was a favorite role for actresses, like Mrs Charles Kemble and Mrs Vining, in the tradition of the "Principal Boy" of the pantomime" (Garber 313). Loose-fitting trousers were common to the oriental and slave costumes, and contributed to shedding doubt on the gender of the actress $^{22}$. If this instance of cross-dressing - this exotic male costume worn amid the series of traditional western female ones during the performance - is most likely to be read as a reference to a theatrical practice of the time, the overall conception of gender as a role also alludes to the practice of cross-dressing as it was featured on the Elizabethan stage. As Marianne Novy explains in Love's Argument, Gender Relations in Shakespeare, "just as Shakespeare found his imagination struck by the stage's transformation of subject to King and back again, he seems to have been fascinated by the image of gender as a role" (Novy 1984 188). This also seems to be true for this particular poem by Emily Dickinson, in which gender is above all a performance and in 
which "womanliness is simply a matter of acting" (Orgel 70), to use Stephen Orgel's terms in Impersonations, The Performance of Gender in Shakespeare's England. The body, underneath the label ("wife," "girl," "woman" or "czar") and the costume, remains mysterious. Therefore, the emphasis laid on the speaker's femininity, along with the kind of "gender trouble" brought on by the presence of the term "czar," are at one with the kind of gender negotiations taking place in Shakespeare's comedies, in which the cross-dressed heroines (played by boys disguised as women pretending to be boys) emphasize their masculinity while punning on their underlying femininity. One could think in this respect of Viola - posing as a "eunuch" $(I, 2,56)$, and whose own body is quite mysterious, because of its resemblance and interchangeability with her brother's ("An apple cleft in two is no more twin / Than these two creatures. Which is Sebastian?" V, 1, 218-219) - in act II, scene 4: "We men may say more, swear more; but indeed / Our shows are more than will; for still we prove / Much in our vows but little in our love" (II, 4, 116-118). The pun hinges here on the possibility to confuse "We men" and "Women" as one hears Viola's tirade; the perspective, along with the gender of the speaker, is easily reversed ${ }^{23}$. In Dickinson's poem, the perspective shifts from a female to a male "I," to a neutral (lines 5-6), and then back to a female perspective. This effect of constant shifting can also be observed in Viola's musings in act II, scene 2:

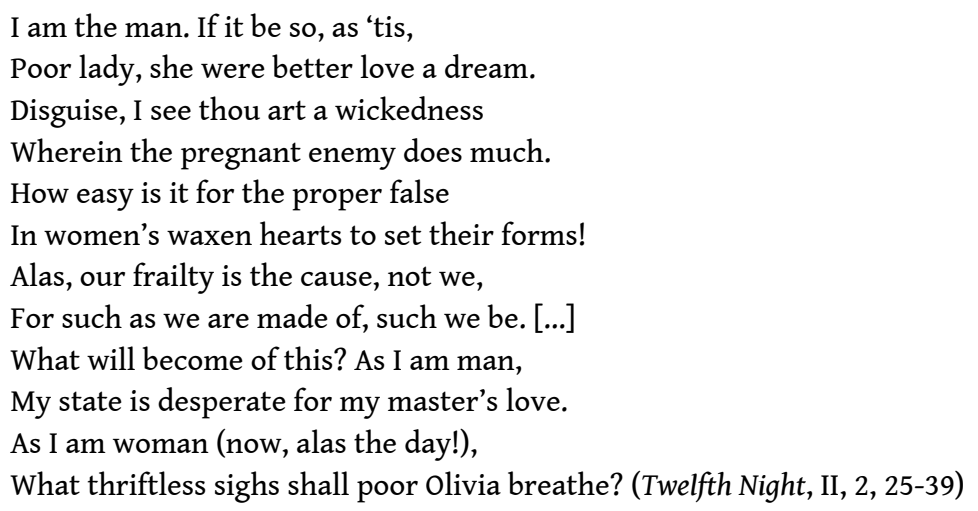

17 As in Dickinson's poem, the gender-neutral pronoun "I" successively refers to a male and to a female speaker. The perspective on women ("How odd the Girl's life looks / Behind this Soft Eclipse" and "How easy is it for the proper false / In women's waxen hearts to set their forms!") is not specifically gendered in both the poem and the passage from Twelfth Night, nor is the pronoun "our" used by Viola, thus allowing extensive play on the gender of the speaker. Overall, the "I" remains an obscure entity, a "thing of darkness" (The Tempest, V, 1, 275), changing gender and costume according to the contingencies of the performance.

The poem thus offers a complex performance of identity, echoing that of Shakespearean heroines in the comedies, and also features the same dynamics of exhibition and dissimulation as evoked previously. Indeed, the repetition of the demonstrative "that" ("I've finished that - / That other state") repeatedly points to a mysterious anterior state, which remains undefined despite the insistence. Similarly, the overwhelming presence of the pronoun " $\mathrm{I}$ " in the first stanza is contrasted by the absence of a stable identity: the "I" remains, in Nancy Walker's terms, a "multifaceted nobody" (Walker 295), giving the illusion of the exhibition of an excessively defined identity, which in the end dilutes the self in a multitude of reflections, a "concert of personalizations called I" (Cixous 92). These fluctuations in identity are characteristic 
of the lyrical self: "underneath any declaration of identity, one can always hear alterity and alteration" (Maulpoix 159) ${ }^{24}$.

The act of borrowing other voices is also particularly significant for nineteenth-century women writers, according to Glennis Byron:

The dramatic monologue would certainly appear to be a useful form for [...] women poets given the traditional gendering of the speaking subject as male and the tendency to associate women writers with the personal and self-representational. Speaking in the voice of a dramatized 'I' allows women to assume the position of the authoritative speaking subject while insisting that the voice is not to be identified as her own. (Byron 81)

In Dickinson's poem, the lyrical illusion consists in making the reader believe in an apparent confessional dimension, while attempting to lose him by all possible means, entangling him in multiple voices, multiple images, and constant shifts of perspective. Moreover, resorting to Shakespearean cross-dressed voices creates the impression that the voice is "twice removed," since it is the voice of a self speaking in the name of another, who is also posing as someone else, being cross-dressed and speaking as a man. This process of distancing and encrypting - disguising and encoding - the voice brings forth a "crypt-self, an encrypted self" (Maulpoix 159). The encryption operates on the level of the encoding of the Shakespearean text and of the self's identity, but also on the level of the self's transformation into a "crypt-self," which carries with it the ghosts of other voices, "the remnants of its chimaeras and of its potentialities" 25 (Maulpoix 159). For Dickinson, this distancing of the self is not so much the expression of Victorian modesty, as it is an attempt to encrypt ${ }^{26}$ the self - in every meaning of the term - and to make it as elusive as possible.

\section{(Over)hearing Dickinson's lyrical voice}

21 If Dickinson - both in the creation of her public persona and of a "multifaceted" poetic self - seems to be playing a game of hide and seek with her audience, by exhibiting a recluse persona, and by showcasing an evasive voice in her poems, the lyrical game is also playing with the idea of the legitimacy of its audience. As the editors of the collection of essays on Dickinson and Audience write, "the lyric poet never addresses an audience but only can be overheard" (Orzeck and Weisbuch 2). In this respect, the reader of Dickinson's poetry is necessarily placed in the position of an eavesdropper, intruding on an outpouring of intimate feelings. This seems particularly true for the poems that were sent with a letter: the intimate quality of the correspondence places the poem in a private setting, and apparently endows it with a highly personal dimension. However, as Páraic Finnerty explains, reading letters aloud was a common practice in Dickinson's time:

Dickinson frequently read letters among her circle of female friends, and she remained the chief reader of newspapers, poems, books, and letters in her family. Her cousins [...] attested to having heard her read her poems aloud. This accomplished reader would have expected her own readers, who shared her education in rhetoric and declamation, to perform her poems and letters aloud. (Finnerty 49)

22 The consecutive use of some poems in different letters sent to different addressees ${ }^{27}$ also considerably limits the intimacy of such exchanges, and in the end, such staging of the poems amounts to a form of dramatized overhearing, and a dramatization of the 
act of reading itself. The theatrical - and Shakespearean - quality of Dickinson's lyric writing has been notably underlined by Susan Howe in her analysis of Dickinson's use of the dramatic monologue: "Anonymous shape-changer, she carried the concealing farther. Her poems are monologues without a named narrator, their supreme source is Shakespeare" (Howe 71). This "shape-changing" and "concealing" of a self that would utter the dramatic monologue is illustrated in poem *365 "Dare you see a Soul at the White Heat?", which also raises the question of the relation between the problematic voice and its audience. In traditional conceptions of the lyric mode, there is no direct interaction with the reader, as Jonathan Culler explains:

In this schema the lyric is defined by John Stuart Mill's aphorism: the lyric is not heard but overheard. The lyric poet normally pretends to be talking to himself or to someone else: a spirit of nature, a Muse, a personal friend, a lover, a god, a personified abstraction, or a natural object. ... The poet, so to speak, turns his back on his listeners. (Culler 137)

Instead of "turning its back" on the reader, poem *365 opens very dramatically on a direct address:

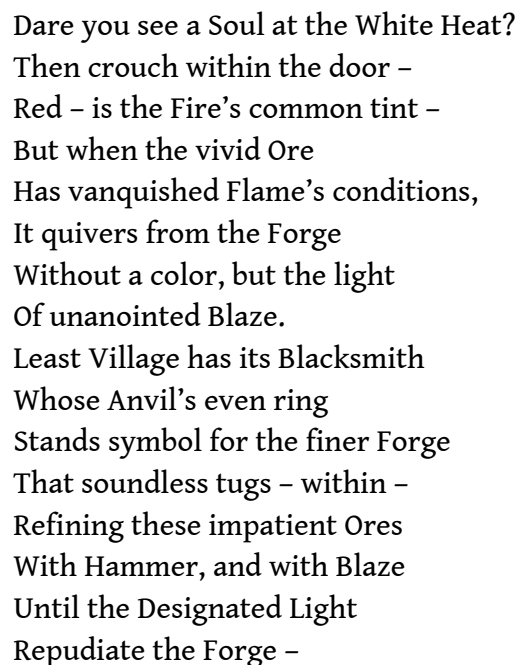

The relation between the subject and the addressee is established in the first two lines, with the apostrophe followed by the order to "crouch within the door." This form of apostrophe to the reader alludes to the genre of the dramatic prologue, which, as Anny Crunelle-Vanrigh notes in her article "Henry $V$ as a Royal Entry," traditionally works as "a threshold into the play" (Crunelle-Vanrigh 360). In Dickinson's poem, the first two lines materialize the threshold into the forge and also work as a threshold into the poem. The invitation addressed to the reader to enter and stop, and the submissive position imposed on the latter ("then crouch within the door," line 2) create a certain distance between the voice and the reader, while they are confined in the enclosed space of the forge. This disposition is comparable to that of the Shakespearean theater: the theatrical illusion only rests on the fact that the audience is extremely close to the stage, and has the impression of seeing all the tricks, while having the desire to "be illusioned" (Green 53) and agreeing to a "suspension of disbelief." As Henri Fluchère explains,

The magic of the theater is always performed openly, [...] in front of an audience standing very close to the stage; the prestige of the show solely depends on the higher position of the stage [...] - which allows the dramatist, with hardly any accessories - each attempt at creating a scenery, each element of the stage thereby 
taking on a symbolic value - to make full use of this absence of a clear localization, this "neutrality" of the stage (Fluchère 142). ${ }^{28}$

The stage is indeed quite bare in this poem: the color melts away, the original red ("Red - is the Fire's common tint") turns into blinding colorlessness ("Without a color, but the light/ of unanointed Blaze."). The fire imagery, as well as the metatextual metaphors of creation and imagination all echo the prologue of Shakespeare's Henry V; in both cases, the contrast is emphasized between the object of the performance (the confrontation with the human soul, or the conflict between "two mighty monarchies," Henry $V$, prologue, 20), and the common, even vulgar, nature of its location (the village forge, and the "unworthy scaffold," the "cock-pit," Henry V, prologue, 10-11). In Dickinson's poem, the tempo is given, like a metronome, by the "anvil's even ring," which sets the tone for the dynamics of echoes at play within the poem. Like the spectators of Shakespeare's prologue, the spectator in Dickinson's poem is invited to appeal to his physical senses so that the performance can actually take place: while Shakespeare's spectators had to imagine they "saw" the prints left by the horses' hooves (Henry V, prologue, 26-27) and felt the oppressing presence of the multitude of soldiers "crammed" within a very small space (Henry V, prologue, 12-14), Dickinson's spectator can only feel the pulsating material ${ }^{29}$ ("quivers," "soundless tugs - within"), and not actually see the soul, blinded as he is by the incandescence of the fire. The submissive spectator is thus only given a negative image, the melting away of the "soul" into an unrecognizable form instead of its being shaped on the anvil. Moreover, the "even ring" can also be read as alluding to a circular space, and in that case is an echo to the Shakespearean "wooden O" (Henry V, prologue, 13) - on which is now played the enigmatic scene of the unshaping of the soul. More than ever, the spectator's "imaginary forces" (Henry V, prologue, 18) are tried, since, as everything disappears, language is the only tangible element that remains. The representation of the scene and of the self solely depends on the echo language will find in the addressee's mind; this relationship with the audience is the key to the completion of the self-fashioning process. Culler further remarks that "the vocative of apostrophe is a device which the poetic voice uses to establish with an object a relationship which helps to constitute him" (Culler 142): in the case of poem *365, only the presence of the voice is truly asserted. Its echo in the forge is made stronger by the absence of a physical shell that would contain it; it is as if the constitution of the self was only possible through the resonance of the sound waves against the bodies and objects present in the forge, and through the echo their only physical trace - the poem - will find in its reader. The performative power of language is at the core of this enigmatic performance, during which all that "happens" is the dissolution of the form. "Nothing need happen in an apostrophic poem [...]. Nothing need happen because the poem itself is to be the happening" (Culler 149). The poem is only the theater of a voice that vanishes when both the voice and the "designated light" simultaneously exit the poem and the forge, as an actor leaves the stage at the end of a scene. Like the soul that is being (un)modeled on the anvil, the performance remains liminal, oscillating between the lyrical and the theatrical; a prologue, a development with multiple transformations, and a dramatic exit unfold within the small framework of the poem. Such condensation of non-events is pushed further into abstraction as the Shakespearean practice of "making nothing out of nothing" (King Lear, I, 4), of giving birth to an illusion on a bare stage, is reenacted quite literally, in a poem that offers an incorporeal performance, delivered by a voice that is at best indirectly heard through 
the reading aloud of the poem. To return to the opening interrogation, the problem here is not overhearing the lyrical voice, but connecting with the voice that utters the apostrophe. Like the voices of the characters in a play, Dickinson's lyrical voice is necessarily bodiless ${ }^{30}$, and needs to inhabit the body of another in order to have an audible existence. The poem, like a play, thus becomes the unifying unit enclosing all the voices, as well as the locus and instrument of the voices' necessary alienation.

The lyrical voice itself - as we have seen - is not a single voice, but a web of voices, made of the self's disguises, of the voices of other poets, and of the influences that have helped to shape it. While her contemporaries were striving to "disinfect" ${ }^{31}$ their voice from the overwhelming British influence, Dickinson seems to fully embrace and acknowledge Shakespeare's dramatic voice as a part of her own lyrical voice. The influence of Shakespearean theatricality on the construction of Dickinson's lyrical self is particularly palpable in her equation of the lyrical self with an actor, an "o without a figure" (King Lear, I, 4, 174), a nomadic linguistic construct, as well as in her practice of dramatic illusion. In the end the lyrical and theatrical modes operate the same attraction, the same bewitching, of the reader, who, although he knows what he is given to see isn't real, willingly accepts the illusion, accepts to become entrapped by the performance while it lasts. Dickinson's stand of "looking back" to Shakespeare in the process of constructing her literary self - thus apparently going against the tide of her contemporaries looking to the future of American literature - is, as Adrienne Rich explains in her essay "When We Dead Awaken: Writing as Revision," an empowering act of self-discovery ${ }^{32}$ for a nineteenth-century New England woman writer. This exploration of the voice of a controversial ${ }^{33}$, albeit canonical, author allowed Emily Dickinson to shape her own unique and modern voice, and also triggers interrogations towards the literary self which in many respects prefigure modernist interrogations about identity ${ }^{34}$.

"When Dickinson tells Sanborn that the 'Future' of literature is Shakespeare, she is speaking of his universality, not his nationality" 35 (Finnerty 82): Dickinson's looking back to Shakespeare, her extensive playing with and appropriation through a reencoding of the Shakespearean intertext is not therefore to be seen only as a political act of Americanization of a British author, as her contemporaries might have considered it. Through her constant exploration of Shakespearean negotiations of selfhood, not only does Dickinson "adopt and adapt" (Granqvist 17), but she also uses Shakespeare as a vehicle of modernity. The Shakespearean conception of a protean self, often breaking out of fixed gender categories, is thus paving the way for the very modern construction of an impersonal self, enacting impersonality through successive fragmentations of the self and an escape from boundaries of selfhood more generally. In her chapter on "Simone Weil's performance of impersonality," Sharon Cameron explains that "genius inheres in the brilliance of seeing outside of one's perspective and outside of perspective generally, in 'that attention that is so full that the 'I' disappears"' (Cameron 117). Such "performance of impersonality" and "seeing outside of one's perspective" is also enacted in Dickinson's writing through the constant encryption of the self - the mark of true literary genius according to Cameron, since "only genius could tolerate such a position without seeking to orient itself. Only genius, indifferent to outcome, could regard this vertiginous state as a foundation" (Cameron 118). 


\section{BIBLIOGRAPHIE}

\section{Primary sources:}

DICKINSON, Emily. The Poems of Emily Dickinson. Ed. Thomas H. Johnson, 3 volumes. Cambridge, MA: The Belknap Press of Harvard University Press, 1955.

---. The Letters of Emily Dickinson. Ed. Thomas H. Johnson and Theodora Ward. Cambridge, MA: The Belknap Press of Harvard University Press, 1958.

\section{Secondary sources:}

AUSTIN, John Langshaw. How to Do Things with Words. Cambridge, MA: Harvard University Press, 1962.

BAKHTIN, Mikhaïl. L'œuvre de François Rabelais et la culture populaire au moyen âge et sous la renaissance. Paris : Gallimard, 1972.

BENVENISTE, Emile. "Le jeu comme structure," in Deucalion : Cahiers de Philosophie, $\mathrm{N}^{\circ} 2$. Paris : La revue Fontaine, 1947, 159-167.

BRISTOL, Michael. Shakespeare's America, America's Shakespeare. London: Methuen, 1990.

BUTLER, Judith. Gender Trouble: Feminism and the Subversion of Identity. New York: Routledge, 1990.

---. "Performative Acts and Gender Constitution: an Essay in Phenomenology and Feminist Theory," in Case, Sue Ellen (ed.). Performing Feminisms: Feminist Critical Theory and Theatre. Baltimore: Johns Hopkins University Press, 1990, 270-282.

BYRON, Glennis. "Rethinking the Dramatic Monologue: Victorian Women Poets and Social Critique," in Chapman, Allison (ed.). Victorian Women Poets. Cambridge: D.S. Brewer, 2003, 79-99.

CAILLOIS, Roger. Les jeux et les hommes : le masque et le vertige. Paris : Gallimard, 1967.

CAMERON, Sharon. Impersonality. Chicago: Chicago University Press, 2007.

CIXOUS, Hélène. "Sorties: out and out: Attacks / Ways out / Forays," in Belsey, Catherine and Jane Moore (eds.). The Feminist Reader (second edition), Essays in Gender and the Politics of Literary Criticism. London: Mac Millan, 1997, 91-104.

COMBE, Dominique. "La référence dédoublée, le sujet lyrique entre fiction et autobiographie," in Rabaté, Dominique (ed.). Figures du sujet lyrique. Paris : PUF, 1996, 39-65.

COMPAGNON, Antoine. La seconde main ou le travail de la citation. Paris : Seuil, 1979.

CRUNELLE-VANRIGH, Anny. "Henry V as a Royal Entry," Studies in English Literature, 1500-1900, Vol. 47, 2, Spring 2007, 355-377.

CULLER, Jonathan. The Pursuit of Signs, Semiotics, Literature, Deconstruction. Ithaca: Cornell University Press, 2001.

FARNHAM, William. Shakespearean Grotesque, Its Genesis and Transformations. Oxford: Oxford University Press, 1971. 
FINNERTY, Páraic. Emily Dickinson's Shakespeare. Amherst: University of Massachusetts Press, 2006.

---. “'No Matter - now - Sweet - But when I'm Earl': Dickinson's Shakespearean Cross-Dressing," The Emily Dickinson Journal, Vol. 7, 2, Fall 1998, 65-94.

FLUCHERE, Henri. Shakespeare, dramaturge élisabéthain. Paris : Gallimard, 1966.

FRETZ, Eric. “P.T. Barnum's Theatrical Selfhood and the Nineteenth-Century Culture of Exhibition," in Garland-Thomson, Rosemarie (ed.). Freakery, Cultural Spectacles of the Extraordinary Body. New York: New York University Press, 1996, 97-108.

GARBER, Marjorie. Vested Interests, Cross-dressing and Cultural Anxiety. New York and London: Routledge, 1992.

GRANQVIST, Raoul. Imitation as Resistance, Appropriations of English Literature in Nineteenth-century America. Madison, Teaneck: Fairleigh Dickinson University Press, 1995.

GREEN, André. Hamlet et Hamlet. Une interprétation psychanalytique de la représentation. Paris : Balland, 1982.

GREENBLATT, Stephen. Renaissance Self-fashioning: From More to Shakespeare. Chicago: University of Chicago Press, 1980.

---. "Fiction and Friction," in HellerThomas C., Sosna Morton and David Wellbery (eds.). Reconstructing Individualism, Autonomy, Individuality and the Self in Western Thought. Stanford: Stanford University Press, 1986, 30-53.

JUHASZ, Suzanne, Cristanne Miller, and Martha Nell Smith. Comic Power in Emily Dickinson. Austin: University of Texas Press, 1993.

LEVINE, Lawrence W. Highbrow/Lowbrow, The Emergence of Cultural Hierarchy in America. Cambridge, MA: Harvard University Press, 1990.

MAULPOIX, Jean-Michel. "La quatrième personne du singulier; esquisse de portrait du sujet lyrique moderne," in Rabaté, Dominique (ed.) Figures du sujet lyrique. Paris : PUF, 1996, 147-161.

MESSMER, Marietta. A Vice for Voices, Reading Emily Dickinson's Correspondence. Amherst: University of Massachusetts Press, 2001.

NOVY, Marianne (ed.). Women's Revisions of Shakespeare; On the Responses of Dickinson, Woolf, Rich, HD, George Eliot and others. Urbana and Chicago: University of Illinois Press, 1990.

---. Love's Argument, Gender Relations in Shakespeare. Chapel Hill and London: University of North Carolina Press, 1984.

ORGEL, Stephen. Impersonations, The Performance of Gender in Shakespeare's England. Cambridge: Cambridge University Press, 1996.

ORZECK, Martin, and Robert Weisbuch (eds.). Dickinson and Audience. Ann Arbor: University of Michigan Press, 1996.

PEARSALL, Cornelia. “The Dramatic Monologue,” in Bristow, Joseph (ed.). The Cambridge Companion to Victorian Poetry. Cambridge: Cambridge University Press, 2000, 67-89.

PHILLIPS, Elizabeth. Emily Dickinson, Personae and Performance. University Park: Penn State University Press, 1996.

RICH, Adrienne. "When We Dead awaken: Writing as Revision," in Adrienne Rich's Poetry and Prose. Ed. Barbara Charlesworth Gelpi and Albert Gelpi. New York and London: Norton, 1993, 166-177. 
SAVINEL, Christine. Emily Dickinson et la grammaire du secret. Lyon : Presses universitaires de Lyon, 1993.

SEWALL, Richard B. The Life of Emily Dickinson. Cambridge, MA: Harvard University Press, 2003.

TUCKER, Herbert. "Dramatic Monologue and the Overhearing of Lyric," in Hosek, Chaviva and Patricia Parker (eds.). Lyric Poetry: Beyond New Criticism. Ithaca: Cornell University Press, 1985, 226-243.

WALKER, Nancy. “'Wider than the Sky', Public Presence and Private Self in Dickinson, James and Woolf," in Benstock, Shari (ed.). The Private Self: Theory and Practice of Women's Autobiographical Writings. Chapel Hill: University of North Carolina Press, 1988, 272, 305.

WEIMANN, Robert. Shakespeare and the Popular Tradition in the Theater, Studies in the Social Dimension of Dramatic Form and Function. Baltimore: The Johns Hopkins University Press, 1987.

WEISBUCH, Robert. Atlantic Double-Cross, American Literature and British Influence in the Age of Emerson. Chicago: University of Chicago Press, 1986.

WINNICOTT, Donald Woods. Playing and Reality [1971]. London: Routledge, 1999.

WOLFSON, Susan. "Explaining to her sisters, Mary Lamb's Tales From Shakespeare," in Novy, Marianne (ed.). Women's Revisions of Shakespeare; On the Responses of Dickinson, Woolf, Rich, HD, George Eliot and others. Urbana and Chicago: University of Illinois Press, 1990, 16-41.

\section{Other works cited:}

HAWTHORNE, Nathaniel. The Scarlet Letter [1850]. London and New York: Penguin, 1986.

SHAKESPEARE, William. Henry V, The Oxford Shakespeare, The Complete Works. Ed. Stanley Wells and Gary Taylor. Oxford: Clarendon Press, 2006.

---. Twelfth Night, The Oxford Shakespeare, The Complete Works. Ed. Stanley Wells and Gary Taylor. Oxford: Clarendon Press, 2006.

WOOLF, Virginia. Orlando [1928]. New York: Harcourt, 2006.

\section{NOTES}

1. For most of Dickinson's New England contemporaries, the relation to Shakespeare was ambiguous, in the sense that the Bard represented both a paragon of literary genius, the ultimate role model for an emerging American literature, while also embodying the old colonial past that needed to be done away with; Whitman thus faulted Shakespeare with "exhal[ing] that principle of caste which we Americans have come on earth to destroy" (Weisbuch 67). See Weisbuch's first chapter "The Burden of Britain and the American writer," 16-18.

2. As Susan J. Wolfson explains in her article "Explaining to her sisters: Mary Lamb's Tales from Shakespeare," young women's access to Shakespeare was very often restricted to such simplified versions of the plays, whereas their brothers were allowed from a very young age to "look into this manly book" (Novy 16).

3. George Gould was one of the editors of The Indicator, one of the two student magazines of Amherst College, and the valentine she sent him in February 1850 -referred to in Johnson's edition of her correspondence as L_34- was published that same month in the magazine.

4. Emily Fowler Ford recalls Dickinson's reaction to the tutors' attempt at censorship: "We had a Shakespeare Club -a rare thing in those days- and one of the tutors proposed to take all the 
copies of all the members and mark out the questionable passages. [...] I remember the lofty air with which Emily took her departure, saying, 'There's nothing wicked in Shakespeare, and if there is I don't want to know it." Quoted in Mabel Loomis Todd, Letters of Emily Dickinson, Boston, Roberts Brothers, 1894, 129-30.

5. Her opinion on this subject can be read in an August 1881 letter to Mrs. Holland, in which she writes: "Shakespeare was never accused of writing Bacon's works, though to have been suspected of writing his, was the most beautiful stigma of Bacon's Life -Higher, is the doom of the High" (L_721).

6. Howe notably compares Dickinson's use of the dramatic monologue to Browning's: "Dickinson and Browning were instinctive masters of the art of dramatic Monologue. [...] In a shorter space (woman's quick voice) Dickinson went further than Browning, coding and erasing - deciphering the idea of herself, dissimulation in revelation" (Howe 71-76).

7. This is a fragment of a letter Mabel Loomis Todd wrote to her parents in 1881.

8. Higginson's criticism of Dickinson's style can be derived from her answer in L_265: "You think my gait "spasmodic" - I am in danger - Sir - ".

9. Higginson published his Letter to a Young Contributor in the April 1862 issue of The Atlantic Monthly, giving advice to hopeful writers; Dickinson sent him her first letter on April 15 (L_260), in which she famously asks if her "verse is alive" and if it "breathe[s]." The letter's rhythm is very slow, because of the numerous dashes, which, precisely, make the letter "breathe," giving it a whispery, hesitant tone. This apparent hesitation, as well as the fact that Dickinson did not sign the letter but enclosed her name in a separate envelope, has been interpreted as a sign of shyness; however, we could also postulate that, given the strangeness of the letter, the extravagant display of modesty, and the unobtrusive reference to Shakespeare ("since Honor is its own pawn," a reference to The Two Gentlemen of Verona, I, 3, 47, "Her honour's pawn," Richard II, I, 1, 74, and IV, 1, 55 "mine honour's pawn," Henry IV, part 2, II, 3, 7, "my honour is at pawn," and cymbeline, I, 6, 194, "pawn mine honour for their safety"), the effect sought is rather to impress her reader, and to distinguish herself from all the other writers that would have also written to Higginson on this occasion.

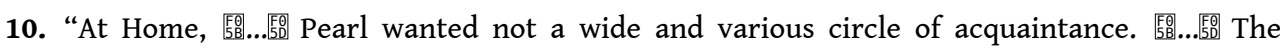
unlikeliest materials, a stick, a bunch of rags, a flower, were the puppets of Pearl's witchcraft, and, without undergoing any outward change, became spiritually adapted to whatever drama occupied the stage of her inner world" (Hawthorne 84-85).

11. "I have no Heavenly Father" (Hawthorne 88).

12. In her second letter, she responds to Higginson's inquiry in those terms: "You asked how old I was? I made no verse - but one or two - until this winter - Sir - " (L_261), and to his request for a portrait, she answers: "Could you believe me - without? I had no portrait, now, but am small, like the Wren, and my Hair is bold, like the Chestnut Bur - and my eyes, like the Sherry in the Glass, that the Guest leaves - Would this do just as well?" (L_268).

13. See Benveniste 161-162, Caillois 60-61, and Winnicott 50-52; in the work of these three authors, playing is defined as a creative activity, during which the player "inhabits" a "precarious" area (Winnicott 51-52), where he is stripped of his own personality in order to assume that which is assigned to him by the rules of the game (Benveniste 162). Following Freud's association in "Creative writers and day-dreaming" between the writer's activity and the child's play, I would argue that Dickinson's letters to Higginson and her early letters to her brother are playing spaces, where the poet and the recipient of the letter both assume personae dictated by the established rules of the game.

14. "In an October 18, 1891, diary entry, Mabel Loomis Todd writes: 'Those (letters) to Mr. Higginson are not of a private nature, and as to the 'innocent' and 'confiding' nature of them, Austin smiles. He says Emily definitely posed in those letters; he knows her thoroughly, through and through, as no one else ever did."' (Messmer 123) 
15. Hepzibah and Clifford are the sister and brother featured in Hawthorne's The House of the Seven Gables; in L_110, Austin, Susan and Emily Dickinson are all associated with characters from Shakespeare's As You Like It.

16. The letters Dickinson wrote to her brother when she was in her early twenties were all vivacious literary jousts; Dickinson had just begun to embrace her literary calling, meanwhile her brother was still seen as the one possessing literary talent, writing witty letters that entertained the whole family. The friendly competition between brother and sister can be seen in L_110 for example: "I've been in the habit myself of writing some few things, and it rather appears to me that you're getting away my patent" (L_110). In this letter as well as in others like L_45, written in 1851, Dickinson frequently challenges her brother, often hiding mockery beneath false modesty and false sisterly submission for a comic effect. As to the romantic rivalry, many critics - like Martha Nell Smith, Paula Bennett, or Judith Farr for example - have offered the hypothesis that Emily Dickinson was in love with Susan, her sister-in-law.

17. In her famous essay "Vesuvius at Home: The Power of Emily Dickinson," Adrienne Rich explains that Dickinson's "little-girl strategy" was a means of subversion and rebellion towards the "career" of "perpetual childhood" (Rich 184) that was offered to women in the nineteenth century.

18. Dickinson's removal from the public eye and her constant disguise behind various masks are what Christine Savinel calls a "mise au secret" (Savinel 13) - an expression whose polysemy is hard to translate, since it refers both to the fact of making something secret, and to the idea of being jailed, and cut out from any communication with the exterior world. This "mise au secret" is in itself a very dramatic act, an outward manifestation of secrecy, articulating the passage between a histrionic (and exhibitionist) performance of modesty - as paradoxical as it may sound - and Dickinson's poetics of secrecy.

19. We will note, however, that the bawdy implications of the term "cuckoo" are not transposed in Dickinson's letter.

20. Martha Nell Smith notes that "when Dickinson produced her cutouts, she did not turn to shopping catalogs and popular magazines so much as she turned to her Bible, her New England Primer, and her father's Dickens, texts considered on the one hand sacred and on the other, inviolable as literary entertainment and guides to proper speech. To observe only that these mutilations of her Bible or of Dickens or of a guide for using language properly are irreverent misses the more important points to be made about them, for these manipulations of texts are transformations, opportunities for Emily Dickinson and her readers to exert control over expression by remaking supposedly fixed utterances and thereby challenge conventional authorities in a constructive way" (Smith 71-72). Such blending of heterogeneous references illustrates Antoine Compagnon's association of the reading activity with a game of "scissors and paste" (Compagnon 17): for Dickinson, reading is not merely playfully rearranging passages and illustrations, but it is also an act of appropriation and, in the case of the Dickens cutouts, of transposition of a canonical British author into an American context. This phenomenon is also illustrated in the way she uses Shakespearean references in her correspondence with Susan: Dickinson is doubly playing a game of "scissors and paste" here, since most of the quotations she uses had already been singled out and rearranged in the "daily Shakespeare calendar" present both in the Dickinson homestead and the Evergreens. Shakespeare's text is thus "twice removed" in the process, as well as transposed twice into an American context.

21. If very little evidence remains on how the Dickinson Homestead was furnished, Emily Dickinson's brother Autin's house - The Evergreens - has retained its original furniture, and features a good amount of oriental objects.

22. The Turkish trousers facilitate this gender confusion. Incidentally, Virginia Woolf's Orlando's gender change happens while the character is in Constantinople, and this costume helps her disguise her newly acquired femininity. Similarly, Sasha's slave attire conceals her gender: “a 
figure, which, whether boy's or woman's, for the loose tunic and trousers of the Russian fashion served to disguise the sex, filled him with the highest curiosity" (Woolf 27-28).

23. One could also quote the passage in the same scene: "I am all the daughters of my father's house, / And all the brothers too" (II, 4, 120-121).

24. "Sous couvert d'une déclaration d'identité, c'est toujours l'altérité et l'altération qui se disent" (Maulpoix 159).

25. "Le sujet lyrique est un sujet plein de voix tues qui sont comme les dépouilles de ses chimères et de ses potentialités. [...] Ce sujet en puissance, mobile et déplacé, devient vers après vers, poème après poème, un sujet crypte, un sujet crypté, un rêve de sujet, un reposoir du sujet" (Maulpoix 159).

26. I use the term "encrypt" in the sense of a "mise au secret" as mentioned earlier on, since the self is both encrypted (encoded, disguised) though language, a crypt-self carrying ghosts of other voices, and also - almost literally - encrypted - put in a crypt - because it is hidden from view, concealed by numerous disguises.

27. Poem *986 "A narrow Fellow in the Grass" has for example been sent twice in different contexts, once to Higginson (L316) and to Susan (L378).

28. “[...] Les fastes du théâtre se déroulent ouvertement, [...] devant un public qui entoure le plateau de très près; l'élévation du plateau seule donne au spectacle son prestige - pourquoi ne pas dire son rehaut - et permet, avec le minimum d'accessoires - chaque amorce de décor, chaque objet, chaque élément de scène prenant une valeur symbolique - d'exploiter aux fins les plus diverses cette absence de localisation, cette 'neutralité' de la scène" (Fluchère 142).

29. The two lines from which these quotations are extracted are written in iambic trimeter, duplicating the heartbeat.

30. Maulpoix defines the lyrical self as a bodiless self that "can only be performed, but has no actual existence." "Le sujet lyrique s'effectue, mais il n'existe pas. Si désireux soit-il, son propre corps lui manque" (Maulpoix 153).

31. I'm borrowing here the term used by James Russel Lowell in "On a certain condescension in foreigners", Prose works, III. New York: Riverside, 1870, 272.

32. "Re-vision - the act of looking back, of seeing with fresh eyes, of entering an old text from a new critical direction - is for women more than a chapter in cultural history: it is an act of survival. Until we can understand the assumptions in which we are drenched we cannot know ourselves. And this drive to self-knowledge, for women, is more than a search for identity: it is part of our refusal of the self-destructiveness of male-dominated society." (Rich 167)

33. Even if Shakespeare had in Dickinson's time become part of the literary canon, he remained quite controversial, especially for female readers; the main reason why women were most often not permitted access to the full texts of the plays was because they were deemed too bawdy to be an appropriate read for young ladies. The puritan reserve towards Shakespeare is also present in Emerson's Representative Men, in which he writes that "the best poet led an obscure and profane life, using his genius for the public amusement." Ralph Waldo Emerson. Representative Men, Seven Lectures. London: Routledge, 1850,135.

34. One could think of Virginia Woolf's interrogations about the mutability of selfhood in works like Orlando for example - a novel which, incidentally, also features strong references to Shakespearean gender negotiations, notably through characters like Orlando, Sasha, the Archduchess Harriet / Archduke Harry (Woolf 131-132), or Shelmerdine (Woolf 184 and 189).

35. See L_402. 


\section{RÉSUMÉS}

Emily Dickinson était une lectrice avide de Shakespeare, et l'on trouve dans son œuvre poétique comme dans sa correspondance de multiples références à ce dernier. Plus qu'un insurpassable modèle littéraire, Shakespeare apparaît, au même titre que sa belle-sœur Susan et Higginson, comme un " tuteur ", un " maître » la guidant dans son écriture. Cet article s'attache à mettre en avant certains aspects de la dimension théâtrale de l'écriture dickinsonienne, ainsi que la manière dont elle est influencée, animée, par la théâtralité shakespearienne, notamment en ce qui concerne la performance (théâtrale et linguistique) du genre et la mise en scène. Les enjeux sont ici multiples; cet article envisage ainsi comment peut s'appréhender le sujet lyrique fortement contaminé par l'élément théâtral, à travers l'étude des différentes mises en scène de l'identité à la fois publique, épistolaire et poétique de l'écrivain américain. Gardant à l'esprit l'idée de John Stuart Mill selon laquelle le lyrique n'a de public que par accident, et les nombreuses études qui présentent Dickinson comme «tournant le dos " à son public, cet article se pose également la question de la relation de la voix poétique avec ce dernier, dans le cadre d'un lyrique théâtralisé.

Emily Dickinson was an avid reader of Shakespeare's works, and several references to his plays and sonnets can be found both in Dickinson's letters and in her poems. Rather than an intimidating and unsurpassable literary figure, shakespeare was as much as a teacher, a mentor, as Higginson or Susan -her sister-in-law and friend- were to the poet. This paper considers Shakespeare's works as a creative matrix to Dickinson's writing, whose own theatricality is also underlined through the study of several performances of identity in the correspondence as well as in the poems. This article also tries to show how Dickinson appropriated elements of Shakespearean theatricality in her poetic work. Bearing in mind John Stuart Mill's conception of the lyric as a genre that can only be "overheard", and the many studies that represent Dickinson as "turning her back" on her readers, we also examine the relations between the poetic voice and her audience.

\section{INDEX}

Keywords : Emily Dickinson, Shakespeare, performance, lyrical/theatrical self and voice, "selffashioning" (Greenblatt)

Mots-clés : Emily Dickinson, Shakespeare, performance, sujet lyrique, théâtralité, "selffashioning" (Greenblatt), voix théâtrale, voix lyrique

\section{AUTEUR}

\section{ADELINE CHEVRIER-BOSSEAU}

Université de Caen Basse-Normandie 